DOI: 10.20472/BMC.2019.009.006

\author{
LAMIA SABOUR ALAOUI \\ Economics and Business, SETTAT University, Morocco
}

\title{
THE IMPORTANCE OF SOCIAL RESPONSIBILITY IN MOROCCO: CASE OF THE SMALL AND MEDIUM ENTERPRISES IN EL JADIDA
}

\begin{abstract}
:
In Morocco the concept of corporate social responsibility has become present in academic research as in the business world. Each company must integrate in its strategy, the implementation of a societal responsibility approach to attract new national and international market. The big Moroccan companies are aware of the importance of this trend, but this notion is still new for Moroccan SME (Small and Medium Enterprise). The purpose of this article is to determine societal responsibility practices in Morocco and in SMEs (Small and Medium Enterprises) in the province of El Jadida in particular. SMEs (Small and Medium Enterprises) in this region have an important role in national industrial development. The first part is devoted to defending social responsibility in general and in Morocco in particular. Next, we identify the social responsibility practices that differentiate the Moroccan small and medium enterprise. For the third part we will present the research methodology and show the results obtained from the survey.
\end{abstract}

\section{Keywords:}

Corporate Social Responsibility, SME, Development, Moroccan companies, The province of El Jadida 


\section{Introduction}

Corporate Social Responsibility was born in the big company to face specific problems (staff motivation, respect for human rights, quality improvement, etc.), For SMEs (Small and Medium Enterprises), their behavior in the face of Social Responsibility is very different from that of large companies (Frimousse, 2013, Jenkins, 2004). Between the authors who consider that " Social Responsibility is only very slightly integrated" in their strategies (Capron \& Quairel Lanoizelée, 2007), SME (Small and Medium Enterprise) engagement in a Social Responsibility approach is less formalized and often supported by the vision of the leader (Frimousse, 2013).

In Morocco, the debate on corporate social responsibility is ubiquitous today, both in the speeches of the business community and in that of academic researchers. The interest that attaches to this subject is due to the fact that Morocco fully plays the card of openness and modernity and the benefits that small and medium entreprises find for the improvement of their competitiveness and the sustainable development of their environment.

Few companies considered the practice of corporate social responsibility as an opportunity, for most companies corporate social responsibility is perceived as an additional cost. Among the factors that can encourage a firm to become socially responsible, the response to market demands, consumer demand or buyer demand is a strong motivation for companies to be responsible.

Companies must meet customer requirements if they want to continue to be competitive and have a good reputation. Firms must choose labels and adhere to standards to improve their brand image.

There are companies that voluntarily choose to become involved in social issues that they feel are right and for which they feel they can bring something extra.

The influence of the STATE is the most important factor that drives each company to adopt corporate social responsibility, these companies most often enter a corporate social responsibility approach for at least two reasons: either in response external pressures, either to prevent possible legislation. Other companies are still trying to prove their ability to selfregulate by setting up corporate social responsibility programs. These firms send the national governments the message that they are able to regulate themselves and that they do not need external intervention by the state to regulate them.

Several SMEs (Small and Medium Enterprises) adopt the Social Responsibility speech, communicate on their Social Responsibility practices and voluntarily choose to apply for certification or certification. Therefore, corporate social responsibility research can not ignore small and medium entreprises and the future development of this concept will depend on its consideration by SMEs. Although their social impact on SMEs is significant, given that they are the dominant form of organizations worldwide, they have received little attention as a Social Responsibility research topic. The purpose of this paper is to determine in the first part the conceptual framework of corporate social responsibility in general and in Morocco in particular. Then we identify corporate social responsibility practices with respect to working conditions. The third part will focus on how SMEs (Small and Medium Enterprise) perceive their social roles. 


\section{Definition of SME in Morocco}

The definition of SME has evolved in Morocco has evolved. Among these texts : the simplified procedure of 1972, the investment code of 1983, the definition of Bank Al Maghrib of 1987, the provisions of FOGAM (Fonds de Garantie de la Mise à Niveau) for the upgrading of SMEs,

The new definition of small and medium entreprises developed by the ANPME ${ }^{1}$ takes into account only the turnover criterion and disregards the size of the company. According to this definition, three types of enterprises are distinguished:

- The very small company: less than 3 million dhs.

- Small business: between 3 and 10 million dhs.

- The average company: between 10 and 175 million dhs.

Small and medium entreprises in manufacturing The Ministry of Industry and Trade relies exclusively on the size criteria measured by the number of employees to determine SMEs (Small and Medium Enterprises). According to this selection, any company employing less than 200 permanent employees is therefore an SME (Small and Medium Enterprise). According to this definition, the number of SMEs (Small and Medium Enterprises) would be estimated at 7262 out of a total of 7812 manufacturing enterprises, ie $93 \%$ of the sector. Moreover, the ministry chose to differentiate between small (less than 50 people) and medium enterprises (50-200), which makes it possible to refine the statistics. According to this differentiation, small firms account for $78 \%$ of the sector, compared with $15 \%$ for averages and only $7 \%$ for large companies ${ }^{2}$.

According to Inforisk ${ }^{3}$, SA data, based on the definition of small and medium entreprises charter, the number of companies with a turnover of less than 75 million dirhams in 2008 and 2009 is around 57,754 companies. According to the same source, 96\% of these companies have a turnover in the last two years less than 3 million dirhams. This clearly shows that the Moroccan economic fabric is, in fact, made up of small to very small enterprises, or even micro enterprises. Moroccan SMEs (Small and Medium Enterprise), Turnover between 3 and 75 million dhs, are present in almost all economic sectors. The following charts show the distribution of 120 SMEs (Small and Medium Enterprises) according to their sector of activity, so there is a predominance in the manufacturing and commercial sector ${ }^{4}$.

\section{Social responsibility and SME}

Bowen (1953) is considered the founder of social responsibility with his book "Social responsibilities of the businessman". The definition of social responsibility is still the subject of research by many researchers and practitioners. For Bowen (1953) and Carroll (1979), the activity of any company has an impact on the lives of citizens, which is why each company has an obligation to make decisions, to implement strategies that must respect the values of the society.

There are several definitions of corporate social responsibility. We can present a few: Corporate social responsibility is the voluntary integration by companies of social and

\footnotetext{
1 The National Agency for the Promotion of Small and Medium Enterprise.

2 Improve the access of SMES to Financing in Morocco; United Nations Conference on Trade and Development; May 2010.

${ }^{3}$ Filiale du groupe Finaccess, fournisseur d'informations légales sur les entreprises.

${ }^{4}$ CDVM : Deontological Council of Securities.
} 
environmental concerns into their business activities and their relations with stakeholders "(European Commission).

The development of work on corporate social responsibility in the 1950s and 1960s and up to the 1980s was marked, in a cold war context, by ideological debates opposing advocates of the idea that business must have responsibilities of its environment and detractors for which the company should have no other goals than maximizing profit to shareholders. Proponents of this vision, which corresponds to the neo-classical Chicago school, consider that the sole and only social responsibility of a firm is to make profits for shareholders the expenses in social projects go to the against the interests of shareholders to the extent that these expenses will have a negative impact on the wealth created by the company for shareholders. The only interest group recognized in this case is the shareholders. For Friedman, entrepreneurs do not have the political legitimacy to manage the common good. Therefore, social responsibility, when it comes out of its minimalist conception of the quest for profit.

Corporate social responsibility aims to solve a problem from three angles: Environmental angle (waste management, reduce water and energy consumption, respect for the environment ...), social angle (Respect for working conditions, financing maternity leave ...), and economic angle (financial performance, respect the principles of competition ...) (Boutillier and Fournier). This phenomenon has become a priority today in the development of the company's strategy (Capron and Quairel-Lanoizelée, 2007).

According to Grond and Igalens (2008), there are four visions of corporate social responsibility:

The "functionalist" approach: Social responsibility as a function of social regulation, this approach apprehends the relationship between company and society, it determines to what extent the goals of the company and those of society can be integrated.

The "sociopolitical" approach: Social responsibility as a relationship of power, this approach is more centered on the dynamics of power and analysis of the relationship between company and society as a balance of power and domination.

The "culturalist" approach: Social responsibility as a cultural product, studies the way in which the company involves social values emanating from its environment.

The "constructivist" approach: Social responsibility as sociocognitive construction is an approach that focuses on the analysis of the mutual construction of the company and society.

Corporate social responsibility as a social function: Corporate social responsibility can be defined as a social regulation instrument that aims to stabilize the interactions between business and society and to facilitate the long-term integration of business goals. The company and society. According to this approach, business and society are conceived as subsystems and interaction, but each has its own different objectives. Corporate Social Responsibility is conceived as an instrument for reconciling the pursuit of profit and social well-being. It is a management tool for integrating corporate objectives with those of the company.

What characterizes this approach is to know how to arrange the objectives of the company with those of the society, by studying the possible relation existing between socially responsible behavior and financial performance. This concept aims to study the links between social responsibility and the financial profit of companies, trying to explain the mechanisms by which firms can profit economically from their social engagement with their stakeholders. . 
Corporate social responsibility as a relationship of power: According to this socio-political perspective, social responsibility, perhaps defined as the expression of power relations, it reflects the power of companies over these actors, and their capacity to resist these pressures or control them. In the context of this approach, unlike the previous one, the question of the relationship between business and society raises the question of the compatibility of the search for profit and the adoption of socially responsible behavior. The corporate / company relationship is therefore a space where power relations are exercised, where each entity seeks to exert control over the other.

Corporate social responsibility as a cultural product: According to this approach, corporate social responsibility is defined as "the product of a culture, that is to say that its content reflects the desirable relations between business and society such as they are defined by the social, cultural and institutional environment ". This vision called "culturalist" attempts to understand the relationship between business and society as an exchange of values and stable cultural referents, and seeks to understand how companies adapt and influence their socio-cultural environment.

According to this approach, the first analysis of social responsibility as the product of an organizational culture aims to determine how normative values can be integrated into the organizational decision process. The second approach focuses on the extent to which historical, cultural and institutional factors influence corporate social responsibility at the global, national and organizational levels.

Corporate social responsibility as sociocognitive construction: According to the constructivist perspective, corporate social responsibility is defined as a sociocognitive construction that is the temporarily stabilized product of a negotiation between the company and society and societal problems ", this approach emphasizes the importance of social representations, standards and value system in the analysis of corporate social responsibility.

The notion of corporate social responsibility is recent for small and medium entreprises (Lapointe and Gendron, 2004). The majority of theories have been presented for application in large companies. Corporate social responsibility enables the small and medium entreprises to survive in the long term and to have a good reputation that will create trust between the company and its customers (Mankelow, 2003) .The relationship with stakeholders and SMEs (Small and Medium Enterprises), is based informal procedures and trust (Jenkins, 2004).

The practice of social responsibility in SMEs (Small and Medium Enterprises) is linked to the personal values of the leader (Jenkins 2009). Most SMEs that adopt corporate social responsibility are exporting companies it is the requirement of foreign customers that pushes them to meet the standards.

\section{Social responsibility in Morocco}

Corporate social responsibility is a new concept in Morocco, either at the level of the private or public sector. It is an evolving field given its importance and its impact on the economic and social development of the country, on the other hand, globalization and international competition requires Moroccan companies to be more efficient.

Morocco is among the most developed countries in Africa. This progress is reflected in the improvement of the infrastructure (ports, airports, highways, etc.). Today, sustainable development is at the center of the country's strategic concerns. 
Subsidiaries of multinational companies are the first to introduce the concept of social responsibility in Morocco. These firms will compete with local businesses, pushing these Moroccan companies to respect environmental and social standards. Competition will therefore be through quality, and firms that have engaged in corporate social responsibility policies (respect for the environment, certifications, labor law, etc.) will have a substantial competitive advantage over others.

The practice of corporate social responsibility is favored by many factors. These factors include: standardization, respect for human rights, the evolution of the labor code, commitments to the protection of the environment, the development of socially responsible investment and the project of sustainable development under the aegis of the Global Compact (Tlemçani, 2009).

\section{Operationalization of corporate social responsibility}

The implementation of a corporate social responsibility policy implies the existence of tools enabling the company to operationalize its commitment in terms of corporate social responsibility. There are several tools among which are labels, certifications, codes of conduct, etc.

\subsection{Standards}

Corporate social responsibility standards are instruments that provide both guidance and credibility to those who submit to them.

According to the classification of the European Commission, we can group these instruments in four categories:

- Declarations of intent (also known as the charter of intent or codes of good practice): these are guidelines that provide lines of thought or lines of action, without providing audit methods and reporting;

- Guidance for management system and certification schemes: they are based on the certification of companies or the accreditation of products (ISO standards).

- The ranking indices used for socially responsible investments, which allow investment funds to identify ethically acceptable companies.

Accountability schemas and reports, which are process-level, process-level guidance that include reporting and ethical accounting systems.

In Morocco, the legal framework of the standardization system was set up in 1970 with the creation of SNIMA (Moroccan Industrial Standardization Service), which is under the Ministry of Commerce and Industry. Currently it is the Moroccan Institute of Normalization (IMANOR) which is the Moroccan official body responsible for standardization, created by the Moroccan legislator in 2010, replacing SNIMA. It is an autonomous public institution administered by a board of directors made up of representatives from the state, the private sector and consumers, and introduces flexibility measures in the process of approving standards. Its missions are: The production of Moroccan standards; Certification of compliance with standards and normative standards; Publishing and dissemination of standards and associated products and related information; Training on standards and techniques for their implementation. 


\subsection{Labels and references}

According to Gendron et al. Labels, also called "labels", are "symbols on products that meet certain pre-established criteria, ecological, biological or social, so that they can be easily identified by consumers".

The CGEM (General Confederation of Enterprises in Morocco) Label for Corporate Social Responsibility is a formal recognition of respect and commitment to observe, defend and promote the universal principles of social responsibility and sustainable development in activities economic and social relations of enterprises.

The aim of the CGEM (General Confederation of Enterprises in Morocco) is to promote the factors of attractiveness of productive investment and long-term growth which are now, human development, respect for the fundamental rights of the human person and the rule of law, quality of employment conditions, the regulation of industrial relations, the protection of the environment, transparency and the effectiveness of competitive rules.

The reference of the Corporate Social Responsibility Label is the charter of social responsibility of the CGEM (General Confederation of Enterprises in Morocco), adopted on December 14, 2006 by the National Council of the Company. This charter is structured in 9 axes of commitment defining each objective of strategy and managerial conduct precise and measurable. These objectives are in line with the guidelines and guidelines of the ISO 26000 standard. They fully comply with national legislation and are fully in line with the principles and objectives set out for business by international public standards, fundamental conventions and recommendations of international institutions. The nine 9 areas of commitment of the Charter Corporate Social Responsibility: Respect human rights, continuously improve the conditions of employment and work and professional relations, protect the environment, prevent corruption, respect the the rules of healthy competition, strengthen the transparency of corporate governance, respect the interests of customers and consumers, promote the social responsibility of suppliers and subcontractors and develop societal commitment.

The CGEM (General Confederation of Enterprises in Morocco) Label for Corporate Social Responsibility is awarded for a period of three years to companies based in Morocco, members of the Confederation, without discrimination of size, sector, products or services. Any company applying for the Label must undergo an evaluation, conducted by one of the independent third-party experts accredited by the CGEM (General Confederation of Enterprises in Morocco). The purpose of this assessment is to certify that the management actions of an applicant company provide reasonable assurance of compliance with the commitments of the Social Responsibility Charter. In particular, this company must provide tangible proof of no violation of the legal obligations contained in this charter.

\section{The practice of social responsibility}

\subsection{Relationship with the environment}

Respect for the environment is an issue of interest not only to environmentalists and environmental groups, but also to other stakeholders such as my consumers, suppliers, certification associations and shareholders. For the company, respect for the environment means pollution control. Finally, several authors take as indicators evaluate the respect of the environment recycling, the conservation of alternative energy (Clarckson, 1998).

Morocco has signed several conventions, including the Convention for the Protection of the Ozone Layer (the Montreal Protocol in 1992, the Vienna Convention and the London and Copenhagen Amendments in 1995), the Convention on in 1995 (the accession to the Kyoto 
Protocol in 2002), the control of transboundary movements of hazardous wastes and their elimination (Basel Convention in 1995, Protocol for the Prevention of Pollution of the Mediterranean Sea in 1999, etc.).

Three new environmental protection laws were promulgated in May 2003. It is a dahir (law) relating to the protection and enhancement of the environment. It determines means of management and protection of the environment as well as provisions setting norms and standards necessary for maintaining the quality of the environment;

The second Dahir relating to environmental impact studies (at the Rio Conference) makes it possible to test the impact of investment projects on the environment. There is also a dahir relating to the fight against air pollution. Companies that do not comply with its laws will have specific sanctions (fines, prison ...).

\subsection{Relationship with employees}

Employees are considered an important part of the business, so the firm must provide its employees with a good work environment, and every company must have a workplace health and safety program in place. We integrate employee training and encouragement of labor union.

The new Labor Code came into force in June 2004. It describes the labor laws that organize social relations within companies. It aims to improve working conditions, establish standards and fundamental principles of labor law. For example, the rules on hours of work, occupational health and types of contracts.

For the types of contracts of recruitment one finds the contract of indefinite duration, the 2nd type of contract is the contract of fixed term, the 3rd type of contract is the temporary employment contract. In addition, in order to better organize the recruitment activity and meet the needs of companies in terms of labor, the public authorities organized non-compulsory intermediation between supply and demand by setting up the National Agency for Employment (ANAPEC).

In terms of weekly hours, there has been a change in legal working hours from 48 hours to 44 hours. In addition, health and safety standards and the regulation of test. This new code prohibits the employment of children under 15, and protects the pregnant woman against dismissal.

\section{Methodology}

The general objective of this research is to verify the nature of the social commitment of firms to the province of El Jadida, we chose as target small and medium enterprises. The survey aims to gather information on the characteristics of SMEs in the province of El Jadida to determine the practice of social responsibility, either in terms of respect for the environment or respect for employees. The questionnaire was developed on the basis of certain dimensions that seek to evolve the management of firms relative to its stakeholders (employees, customers, suppliers, shareholders, etc.). Our questionnaire has three main parts.

Part 1: General Data (Business Line, Employees, Production Destination, Contractor Profile, etc).

Part 2: Perception of corporate social responsibility (knowledge of corporate social responsibility, the number of social or environmental certification standards, the impact of business activity on the environment, etc).

Part 3: The practice of social responsibility (employee relations, raising staff awareness of corporate social responsibility issues, protecting the environment, etc). 
These areas are measured by the following variables: standardization, waste management, flexibility of working hours, transportation for employees, existence of social coverage for employees, continuous training, reducing water and energy consumption.

We were able to contact 61 companies through a telephone and personal survey (appointment). We have approved the agreement of 41 companies. These are Metal and 2 Industrial Boilermaking, 6 Milling, 3 Leather and Footwear, 7 Metal Fabrication, 5 Manufacturing concrete components for construction, 2 for woodworking and manufacture of wooden articles, 5 for the manufacture of animal feed, 3 for textiles and clothing, 8 Other. The response rate of about $67 \%$. This figure is satisfactory given the conditions under which this survey was conducted.

\section{The results}

\subsection{General information about the company}

\section{Figure 1: Category of companies}

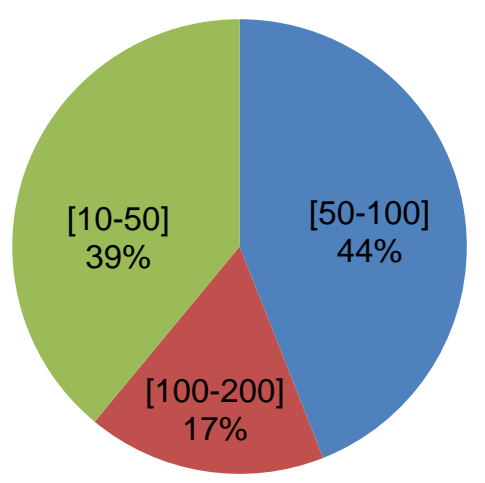

\section{Source: Own data processing}

More than half of the firms are medium-sized firms (44\%) hiring between 50 and 100 employees and (17\%) between 100 and 200. while small firms account for (39\%) between 10 and 50 .

\section{Figure 2: Activity of companies}

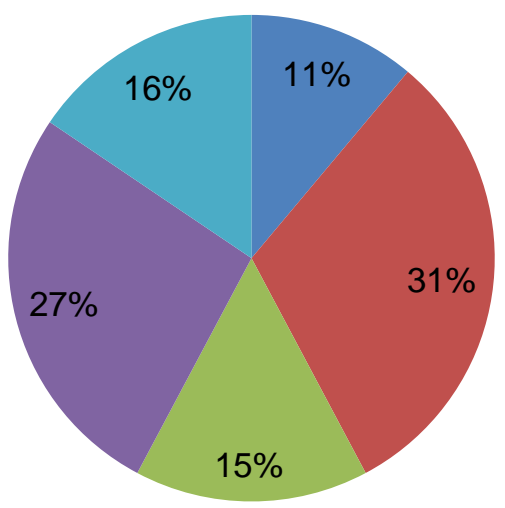
Metal construction and industrial boilermaking
- Milling
- Leather and footwear industry
- Metal construction manufacturing
- Textile and clothing

Source: Own data processing 
Our sample consists of firms operating in the following sectors: Metal construction and industrial boilermaking ( $5 \%$ of the sample); milling ( $14 \%$ of the sample); leather and footwear industry ( $7 \%$ of the sample); metal construction manufacturing (19\% of the sample); manufacture of concrete elements for construction (12\% of the sample); woodworking and manufacture of wood products (5\% of the sample); animal feed manufacturing ( $12 \%$ of the sample); textile and clothing (7\% of the sample). There are 3 groups: $79 \%$ of SMEs involve the local market only. $14 \%$ involves local and foreign markets and $7 \%$ involves the foreign market. We note that $67 \%$ of entrepreneurs are self-taught, $17 \% \mathrm{Bac}+4$ and above, $14 \% \mathrm{Bac}$ level, $2 \% \mathrm{Bac}+3 \mathrm{Bac}$.

\subsection{Perception of corporate social responsibility}

Figure 3: knowledge of corporate social responsibility

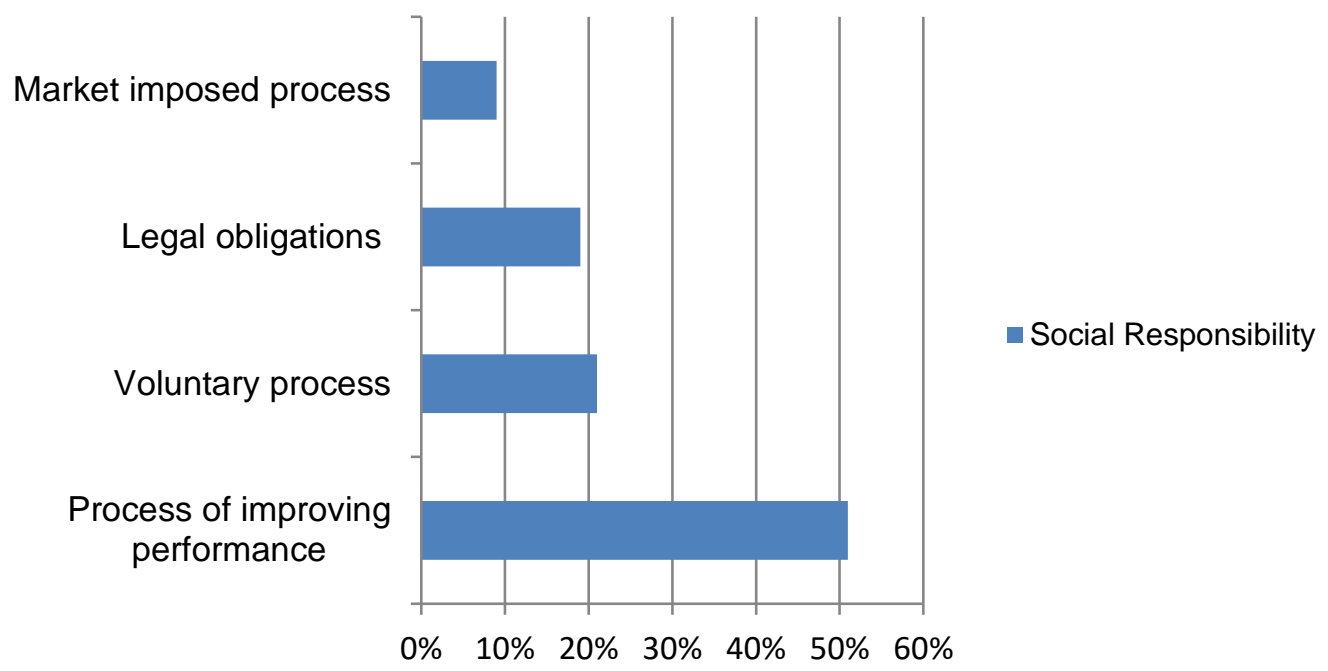

Source: Own data processing

We note that $66 \%$ of the SMEs (Small and Medium Entreprises) in question have an impact on the environment. Only $17 \%$ know about social responsibility but $60 \%$ have never heard of this notion and $23 \%$ have just heard it. $51 \%$ of these companies see that social responsibility is a process of improving performance by taking into account social and environmental factors; for $21 \%$ Social responsibility is a voluntary process that takes into account social and environmental factors; $19 \%$ consider social responsibility as a set of legal obligations to take into account social and environmental factors; and only $9 \%$ who see Social Responsibility as a process imposed by the market to take into account social and environmental factors. 


\subsection{The practice of corporate social responsibility}

- Environmental protection :

\section{Figure 4: Certified companies}

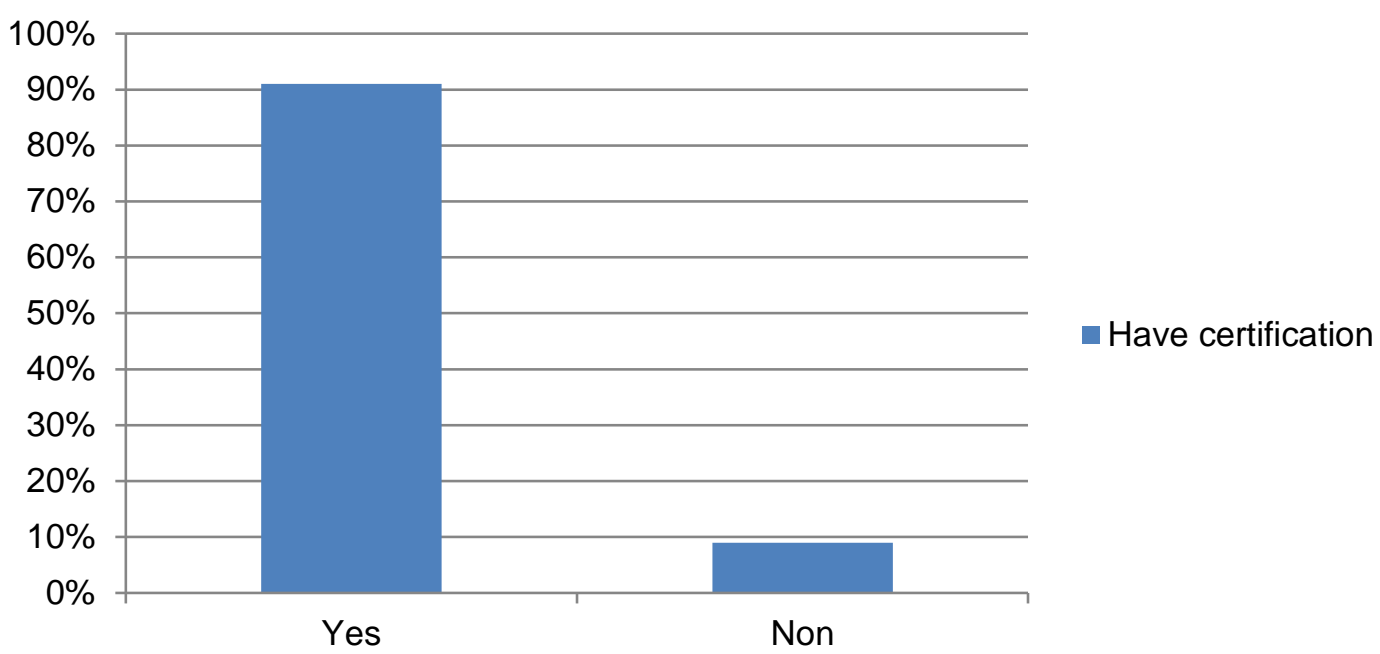

\section{Source: Own data processing}

Only $9 \%$ of respondents say they have obtained certification, while $91 \%$ have not done so. $34 \%$ want to adopt social responsibility instruments in the coming years. The most widely adopted certifications are ISO9001 and ISO 14001.

Only $4 \%$ of respondents say they recycle their products, while $96 \%$ do not. $78 \%$ of respondents have put in place a savings plan to reduce water and energy consumption, while $22 \%$ have never set up such a plan.

- The working conditions of the employees :

Respondents say they respect the right to strike in their company for those who do not respect it; and this despite the fact that it is a right registered in the Labor Code.

$45 \%$ of the respondents declare that they have not respected the right to organize in their company. Against 55\% who respect it, this respect translates into meetings. $94 \%$ of SMEs make annual meetings, $4 \%$ hold monthly meetings and only $2 \%$ do monthly meetings. Encouraging the use of public transport: $21 \%$ of respondents state the existence of public transport;

$12 \%$ of respondents say they contribute to the development of local services within companies through, mosque, restaurant etc. $60 \%$ of respondents say that the first obstacle to implementing its social responsibility policy is the lack of information. $24 \%$ see that there is no profit to be achieved and $14 \%$ are not interested.

\section{Discussion and conclusion}

The literature has shown that firms that integrate the social responsibility dimension into their business have a clear competitive advantage and that this can influence their economic and financial performance.

Corporate social responsibility is a new area for developing countries such as Morocco, each economic development has an impact on the natural environment. Morocco is among the countries that have signed a number of international protocols. This commitment has pushed public authorities to implement environmental protection programs, taking advantage of the 
country's natural renewable energy assets. Exporting companies will have to comply with international environmental standards.

The problematic of social responsibility seemed interesting to us to study in the province of $\mathrm{El}$ Jadida considering the importance of the industrial zone of this city at the level of development of the national industry. These analyzes show that most of the SMEs (Small and Medium Entreprises) in El Jadida province belong to people who are self-taught, which has an impact on the practice of social responsibility because most of these entrepreneurs do not even know the notion of social responsibility. Their main goal is to make profits. It has been noted that medium firms are more socially responsible than small ones. Indeed, medium-sized firms are more likely than small firms to provide transportation to employees, to have a good working relationship with employees. In terms of environmental protection, indeed, can small and medium entreprises that establish plans for energy saving and waste management. As far as certification is concerned, it can be said that, overall, exporting firms are more concerned with the certification process because they have to respect very strict specifications from their foreign customers. At the level of the province of El Jadida certified small and medium entreprises are very can. We find that the certifications to adopt or to wish are ISO9001 and ISO 1400 , this is due to the lack of information.

The results obtained show that, in general, the social and environmental involvement of Moroccan small and medium entreprises remains largely insufficient. On certain dimensions, either at the level of the protection of the environment or the working conditions of the employees, therefore the State must sensitize the companies on the importance of the good practice of social responsibility. Creating trust between SMEs and stakeholders by establishing codes of conduct, for example.

The state must sensitize companies to the importance of the good practice of social responsibility and create codes of conduct, each company must: Appoint a corporate social responsibility manager, train your managers in the principles of corporate social responsibility, examine corporate social responsibility best practices in your sector of activity, work with a renewable energy provider, establish a waste reduction plan, reduce your paper consumption, optimize energy consumption thanks to a plan to reduce energy waste, respect the basic rules of health and hygiene at work (have a doctor at work) and invest in renewable energies.

\section{REFERENCES}

ABBOTT, W.F., et MONSEN, R.J. (1979). On the Measurement of Corporate Social Responsability : Self-Reportrd Disclosures as a Method of Measuring Corporate Social Involvement. Academy of Management Journal, 22(3), 501-515.

BERGER, P., et LUCKMANN, T. (1996). La construction sociale de la réalité. Paris : A .Colin, coll. U.

BECK, U. (1986). La société du risque : sur la voie d'une autre modernité. Paris : Flammarion.

BELAND, P., et PICHE, J. (1998). Faites le bilan social de votre entreprise. Montréal : Les Editions Transcontinental INC et les Editions de l'entrepreneurship.

BURELLE, G., et MORGAN, G. (1979). Sociological Paradigms and Organization Analysis. Elements of the Sociology of Corporate Life. Newcastle : Athenaeum Press.

BOUSSOURA, E., et ZERIBI-BENSLIMANE, O. (2009). "Quelle responsabilité sociétale pour les entreprises tunisiennes cotéées ? " présenté au Colloque International : Responsabilité Sociale de l'Entreprise, ISIAM, Agadir.

BOWEN, H. R. (1953).Social responsibilities of the business man.New York : Harper and Row. 
CAPRON, M., et LANOIZELEE, F. Q. (2007). La responsabilité sociale d'entreprise. Paris : Collection Repère, Editions la Découverte.

CHAMPION, E., et GENDRON, C. (2005). La responsabilité sociétale des acteurs économiques : une perspective nord-américaine. Rapport de recherche du Chantier RSAE.

GHOZZI-NEKHILI, C. (2009). Les pratiques de la GRH au regard de la RSE. Présenté au Colloque International : Responsabilité Sociale de l'Etreprise, ISIAM, Agadir.

IGALENS, J., et GOND, J.P. (2008). La responsabilité sociale d'entreprise. Paris : Puf, collection « Que sais-je ?».

TARIK EL MALKI, (2014). La responsabilité sociale des entreprises. Afrique Orient. 